
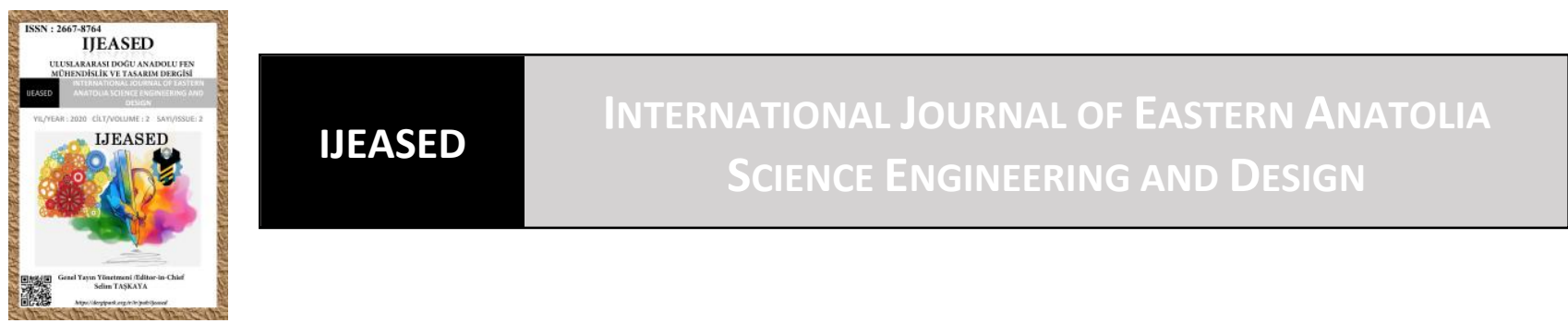

\author{
Uluslararası Doğu Anadolu Fen Mühendislik ve Tasarım Dergisi \\ ISSN: 2667-8764, 2(2), 216-228, 2020 \\ https://dergipark.org.tr/tr/pub/ijeased
}

Derleme Makalesi / Review Article

Doi: $\underline{10.47898 / \text { ijeased.789258 }}$

\title{
Doğada Kendiliğinden Yetişebilen Bitkilerden Doğal Kauçuk Üretimi: Derleme
}

\author{
Özlem KORKUT ${ }^{1 *}$, Ezgi GEREZ ${ }^{1}$
}

${ }^{1}$ Atatürk Üniversitesi, Mühendislik Fakültesi, Kimya Mühendisliği Bölümü, Erzurum, 25240, Türkiye.

\begin{tabular}{l|l|l}
\hline \multicolumn{1}{c|}{ Yazar Kimliği / Author ID (ORCID Number) } & \multicolumn{1}{|c}{ Makale Süreci / Article Process } \\
\hline "Sorumlu Yazar / Corresponding author $:$ & Geliş Tarihi / Received Date $:$ & 02.09 .2020 \\
ozlemkor@ atauni.edu.tr & Revizyon Tarihi / Revision Date : & 27.09 .2020 \\
\hline iD https://orcid.org/0000-0002-1427-9183, Ö. Korkut & Kabul Tarihi / Accepted Date : & 04.10 .2020 \\
iD https://orcid.org/0000-0002-3880-7761, E. Gerez & Yayım Tarihi / Published Date : & 15.12 .2020 \\
\hline
\end{tabular}

Alıntı /Cite : Korkut, Ö., Gerez, E. (2020). Doğada Kendiliğinden Yetişebilen Bitkilerden Doğal Kauçuk Üretimi: Derleme, Uluslararası Doğu Anadolu Fen Mühendislik ve Tasarım Dergisi, 2(2), 216-228.

\begin{abstract}
Özet
Dünya genelinde 2020 yılı içinde gelişen pandemi süreci insan hayatını ve ülkeleri derinden etkilemiştir. Ülkeler ekonomik ve sosyal açıdan daha içe kapalı bir yönetim ve tutum içinde bulunmak zorunda kalmıştır. Pandemi sürecinin ne kadar devam edeceği ve buna benzer süreçlerin gelişip gelişmeyeceği yönündeki belirsizlik ülkeleri sosyal ve özellikle ekonomik açıdan tedbirler almaya zorlayacaktır. Bu tedbirler kapsamında dışa bağımlılıktan kurtulma ve her türlü ihtiyacını kendi zenginlikleriyle karşılayabilme becerisini kazanabilen ülkeler bu tip süreçleri kolaylıkla yürütebilecek ve ekonomik anlamda daha da özgürleşebileceklerdir. Sunulan bu çalışmanın ülkemizde yetişen bitkilerden yararlanarak doğal kauçuk üretimi konusunda yapılacak araştırmalara 1şık tutması amaçlanmıştır. Hayatımızın pek çok alanında kullandığımız doğal kauçuğun üretiminde kullanılan ve dünyada belli bölgelerde yetişebilen kauçuk ağaçlarına alternatif olabilecek, doğada kendiliğinden de yetişebilen bitkiler, bu bitkilerden doğal kauçuğun elde edilme yöntemleri ve doğal kauçuk dişında bu bitkilerden elde edilebilecek ekonomik değeri yüksek maddeler üzerine bir araştırma yapılmıştır. Ülkemizde de hemen her bölgede kendiliğinden yetişebilen pek çok bitkinin katma değeri yüksek pek çok malzemeye temel oluşturabileceği ve bunların ekonomimize kazandırılması için yapılacak her türlü çalışmanın son derece kıymetli olduğu açıkça görülmektedir.
\end{abstract}

Anahtar Kelimeler: Doğal kauçuk, Guayule, Karahindiba, Dikenli marul, Altınbaşak 


\title{
Natural Rubber Production from Plants Growing in Nature: Review
}

\begin{abstract}
The pandemic process that developed worldwide in 2020 has deeply affected human life and countries. Countries were required to develop more enclosed governance and attitudes in economic and social terms. Uncertainties about how long the pandemic process will continue and whether similar processes may occur again, have forced countries to take precautions in social and especially economic terms. Within the scope of these precautions, countries with the ability to cut external dependence and meet all requirements from their own assets can easily cope with these processes and will be freer in an economic sense. This study aims to offer an insight into researchs that will be performed about natural rubber production using plants growing in our country. A research was performed into alternative plants to rubber trees, which only grow in certain areas of the world and are used for natural rubber production required for many areas of our lives. Plants which self-cultivate in nature, methods for obtaining natural rubber from these plants and materials with high economic value, apart from natural rubber, that can be obtained from these plants were studied. Many plants which grow naturally in nearly all regions of our country can form the basis for many types of material with high added value. It is very clear that all types of studies which will include these resources in our economy are very valuable.
\end{abstract}

Keywords: Natural rubber, Guayule, Taraxacum kok-saghyz, Prickly lettuce, Goldenrod

\section{Giriş}

Lateks pek çok bitkinin kesilen bir kısmından süzülen ve hava ile karşılaştığında katılaşarak doğal kauçuğa dönüşen süte benzer bir maddedir. Doğal kauçuğun kaynağı olan ve Euphorbiaceae familyasına ait bitkilerden elde edilen lateks tıp alanında ilk defa XIX. yüzyıl ortalarında, takma dişlerin yapımında kullanılmıştır. 1900’lü yılların başında ilk cerrahi eldivenler sağlık çalışanlarının hizmetine sunulmuştur. Günlük hayatta otomobil lastikleri, halı, yüzme gözlükleri, tenis raketleri, ayakkabı tabanları, bulaşı eldiveni, balon, emzik, biberon, sıcak su şişeleri, silgi ve kemer; tıp alanında ise, stetoskoplar, eldivenler, turnikeler, enjektörler, cerrahi maskeleri, koruyucu gözlükleri, respiratörler, anestezi maskeleri, kateterler, yara direnleri, enjeksiyon portları ve diş malzemeleri lateksin kullanıldığı bazı ürünlerdir. Amerika Birleşik Devletlerinde doğal kauçuk "Ekonominin, savunmanın ve ulusun genel refahı için hayati öneme sahip bir mal” olarak tanımlanmıştır (Ramirez-Cadavid ve ark., 2017).

Günümüzde kullanılan pek çok sentetik kauçuk ürünü petrol türevlerinden üretilir. Dünyada 2011 yılı toplam kauçuk üretimi ve tüketiminin \%57.8'i sentetik kaynaklıdır. Bilim adamları doğal kauçuğun (NR: natural rubber) piroliz ile izoprene (IP) bölünebildiğini fark etmişlerdir. NR 200 ${ }^{\circ} \mathrm{C}$ 'nin altında kararlıdır, daha küçük parçalara ayrıştırma işlemi $290-300{ }^{\circ} \mathrm{C}$ ' de başlar. Piroliz, 450 ${ }^{\circ} \mathrm{C}$ 'nin altında gerçekleştirildiğginde NR'nin ana piroliz ürünü DL-limonendir. $\mathrm{Bu}$ anlayışla Bouchardat,1879'da monomer olarak izopren (IP) ve başlatıcı olarak hidroklorik asit kullanarak poliizopren (PIP) sentezini rapor etmiştir. $\mathrm{Bu}$ araştırma sentetik kauçuk üretimine ait ilgi alanlarını hızla tetiklemiştir ancak yüksek molekül ağırlığına ulaşılamaması ve kürlenmiş PIP'nin mekanik 
özelliklerinin zayıf olması nedeniyle yeterli başarıya ulaşamamıştır (Ching ve Chiang, 2013). Sentetik kauçuk (baskın olarak stiren-butadien polimer) istenen birçok son kullanım özelliklerinden yoksundur. $\mathrm{Bu}$ nedenle sentetik polimerler tamamen doğal kauçuğun yerini tutamazlar. Doğal kauçuk ürünleri çekme mukavemeti, esneklik, elastikiyet, aşınma ve soğuk havalarda darbe dayanımı, verimli 1sı dağılımı ve yumuşaklığa sahiptir. Bu özellikler, tıbbi cihazlar ve uçak lastikleri gibi yüksek performanslı uygulamalarda gerekli özelliklerdir. Sentetik esaslı ürünler yenilenemeyen bir kaynaktan elde edildiğinden, petrol kaynaklarının tükenmesi ve sonunda sentetik malzemelerin üretilememesi nedeniyle doğal kauçukların kullanılması kaçınılmazdır. Doğal kauçuk içeren bitkinin yetiştirilmesi ve ticarileştirilmesi, sentetik kauçuk üretimindeki düşüşe kısa ve uzun vadeli en iyi çözümdür (Hayashi, 2009).

Ülkemizde kauçuk ithalatı oldukça fazla olup, giderek artış göstermektedir. Tablo 1'de kauçuk ithalatının 2017 yılında 482700 ton hammaddeye karşılık 1394 milyon dolar değerinde gerçekleştiği görülmektedir. Hammadde ithalatı 2018 yılında \%21.6'lık bir artış ile 586900 ton olmuş ve karşılığında ödenen ücret \%12.1'lik bir artış ile 1562.3 milyon dolara yükselmiştir (PLASFED, 2018).

Tablo 1. Ülkemize ait doğal kauçuk ihracat ve ithalat verileri

\begin{tabular}{|c|c|c|c|c|c|c|}
\hline \multirow[t]{2}{*}{ İHRACAT } & \multicolumn{2}{|c|}{2017 (Ocak-Haziran) } & \multicolumn{4}{|c|}{2018 (Ocak-Haziran) } \\
\hline & Miktar & Değer & Miktar & \%Değer & Değer & \%Değer \\
\hline Plastik Hammadde & 364.9 & 485.6 & 399.7 & 9.6 & 606.1 & 24.8 \\
\hline Plastik Mamul & 798.5 & 2086.2 & 856.2 & 7.2 & 2352.7 & 12.8 \\
\hline Plastik ve Kauçuk işleme Makineleri & N/A & 78.6 & N/A & N/A & 98.1 & 24.9 \\
\hline Kauçuk & 299.3 & 1197.1 & 335.2 & 12.0 & 1454.8 & 21.5 \\
\hline \multicolumn{7}{|c|}{ Miktar: Bin Ton /Değer: Milyon Dolar } \\
\hline \multirow[t]{2}{*}{ İTHALAT } & \multicolumn{2}{|c|}{2017 (Ocak-Haziran) } & \multicolumn{4}{|c|}{2018 (Ocak-Haziran) } \\
\hline & Miktar & Değer & Miktar & \%Değer & Değer & \%Değer \\
\hline Plastik Hammadde & 3497.9 & 4909.5 & 3787.1 & 8.3 & 5724.3 & 16.6 \\
\hline Plastik Mamul & 300.0 & 1474.5 & 316.8 & 5.6 & 1559.3 & 5.8 \\
\hline Plastik ve Kauçuk işleme Makineleri & N/A & 272.9 & N/A & N/A & 338.2 & 23.9 \\
\hline Kauçuk & 482.7 & 1394.0 & 586.9 & 21.6 & 1562.3 & 12.1 \\
\hline \multicolumn{7}{|c|}{ Miktar: Bin Ton /Değer: Milyon Dolar } \\
\hline \multirow{2}{*}{ TOPLAM DIŞ TİCARET } & \multicolumn{2}{|c|}{2017 (Ocak-Haziran) } & \multicolumn{4}{|c|}{2018 (Ocak-Haziran) } \\
\hline & \multicolumn{2}{|c|}{ Değer } & \multicolumn{2}{|c|}{ Değer } & \multicolumn{2}{|c|}{ \%Değer } \\
\hline İhracat & \multicolumn{2}{|c|}{77375.6} & \multicolumn{2}{|c|}{82222.9} & \multicolumn{2}{|c|}{6.3} \\
\hline İthalat & \multicolumn{2}{|c|}{108319.9} & \multicolumn{2}{|c|}{122960.3} & \multicolumn{2}{|c|}{13.5} \\
\hline
\end{tabular}

Doğal olarak ticari kauçuk elde edilen çok sayıda bitki vardır ve yaklaşık olarak 1800 dikotil bitkide kauçuk bulunmaktadır. Euphorbiaceae familyası, dioik veya monoik, yıllık, iki yıllık veya çok yıllık otlar veya çalılar şeklinde olan lateks denilen süt şeklinde özsuya sahip bitkilerden oluşan bir familyadır (Radcliffe-Smith, 1982). Euphorbiaceae (Sütleğengiller) familyası, dünyada 240 cins 
ve 6000 civarında türle temsil edilirler. Euphorbia L. cinsi, Türkiye'de 120 takson ile temsil edilmekte olup, 18'i Türkiye için endemiktir (Erdoğan ve ark., 2012). Çoğunlukla dallanmış süt boruları (dallanmış eklemsiz latisiferler) bulundururlar. Euphorbia türlerinin sütleri içerisinde tanin, resin, kauçuk, nişasta ve enzimler bulunur. Sütü tahriş edici etkiye sahiptir. Bu bitkilerden elde edilen maddeler ilaç veya hammadde olarak kullanılır (Şenel ve ark., 1996).

Euphorbiaceae familyasından olan Hevea brasiliensis Müll. Arg. (Kauçuk ağacı) dünya ekonomisinde çok önemli bir yer oluşturmaktadır. Bu bitki daha çok Orta Amerika, Brezilya, Liberya, Sumatra ve Java'da yetişmektedir. Hevea lateksinin \%40-50'sini kauçuk oluşturur. Ancak H. brasiliensis ağacından NR arzını tehlikeye atan belirli faktörler şöyle sıralanabilir:

1. Kontrol önlemlerine rağmen kauçuk ağacı tarlalarını hızla yok edebilecek Güney Amerika Yaprak Hastalığı (SALB) dahil olası patojen salgınları,

2. Tropik bölgelerde yetişen $H$. brasiliensis ağacının iklim değişikline karşı savunmasız olması,

3. Çin, Hindistan ve Brezilya gibi gelişmekte olan ülkelerden NR'ye talep artışı,

4. Biyoyakıt taleplerini karşılamak için kauçuk ağacı tarlalarının daha karlı palmiye yağı tarlaları ile yer değiştirmesi,

5. Doğal orman ekosistemlerini yok eden kauçuk ağacı tarlalarının sürdürülemez genişlemesine yönelik sınırlar,

6. NR'ye erişim ve üretimini sınırlandırabilecek jeopolitik faktörler (Ramirez-Cadavid ve ark., 2017).

Tüm bu olumsuzluklar artan talep ile birleştiğinde bu biyolojik ve coğrafi çeşitlilik eksikliği, alternatif NR kaynaklarının geliştirilmesini zorunlu kılmaktadır. Doğal kauçuk içeren otsu bitkiler, yüksek su kullanma verimlilikleri ve kuraklığa karşı dirençleri, hastalık ve haşerelere karşı yüksek mukavemetleri, yüksek fotosentetik etkinlikleri ve biokütle verimlerinin yanı sıra tek veya iki yıllık hasat süreleriyle ağaçlar gibi çok yıllık bitkilere göre daha az başlangıç maliyetine sahip olmaları ve piyasadaki arz talep dalgalanmalarına göre dikme veya üretimden çıkarma esnekliğini sağlayabilmeleri nedeniyle gelecek vadeden NR kaynağı olmaya adaylardır (Bell, 2013).

\section{Doğal kauçuk kaynağı bitkiler}

\subsection{Rus Karahindibası (Taraxacum kok-saghyz Rodin)}

Compositae (Papatyagiller) familyasından olan Taraxacum kok-saghyz (TKS), geleneksel NR kaynağına alternatif olabilecek kauçuk üreten karahindibadır. Compositae (Toplu çiçekgiller) familyasında yer alan bitkilerin ortak özellikleri bir - iki ya da çok yıllık otsu, az olarak da odunsu 
bitkilerdir. Çoğunda süt boruları bulunur. Çiçekleri genelde küçüktür. Meyve fındıksı meyve durumunda, bir tohumludur. Tohumda besin dokusu yoktur. Hemen her yerde doğal olarak bulunmaktadır (MEGEP, 2008). T. kok-saghyz, köklerinde yüksek kaliteli bir kauçuk içeren sütlü bir sıvı üretir. Kauçuk içereği \% 0-15 civarındadır. Uluslararası lastik ve ekipman tedarikçilerinden Continental'in toplum tarafından daha çok bilinen sürdürülebilirlik faaliyetlerinden biri Rus karahindibasından üretilen lastiktir. Şirket Fraunhofer Moleküler Biyoloji ve Uygulamalı Ekoloji Enstitüsü IME ile karahindiba köklerinden elde edilen doğal kauçuğun (ham kauçuk), yağmur ormanlarından elde edilen doğal kauçuğun yerini ticari anlamda almasını sağlamaya çalışmaktadır. Gıda ürünleri için uygun olmayan arazilerde yetiştirilebilen karahindiba ile taşımacılık mesafeleri azalacak, $\mathrm{CO}_{2}$ emisyonunda ciddi bir düşüş oluşurken, lastik üreticileri de global kauçuk piyasasının dengesiz fiyatlarından korunacaktır. Bir otomobil lastiği kauçuğunun yüzde 10 ila 30’unun kauçuk ağacından (Hevea brasiliensis) geldiği düşünüldüğünde, bu durumun faydaları oldukça açıktır (Gürsoy, 2017). Şekil 1' de Atatürk Üniversitesi kampüsünde yetişen karahindibalar görülmektedir.

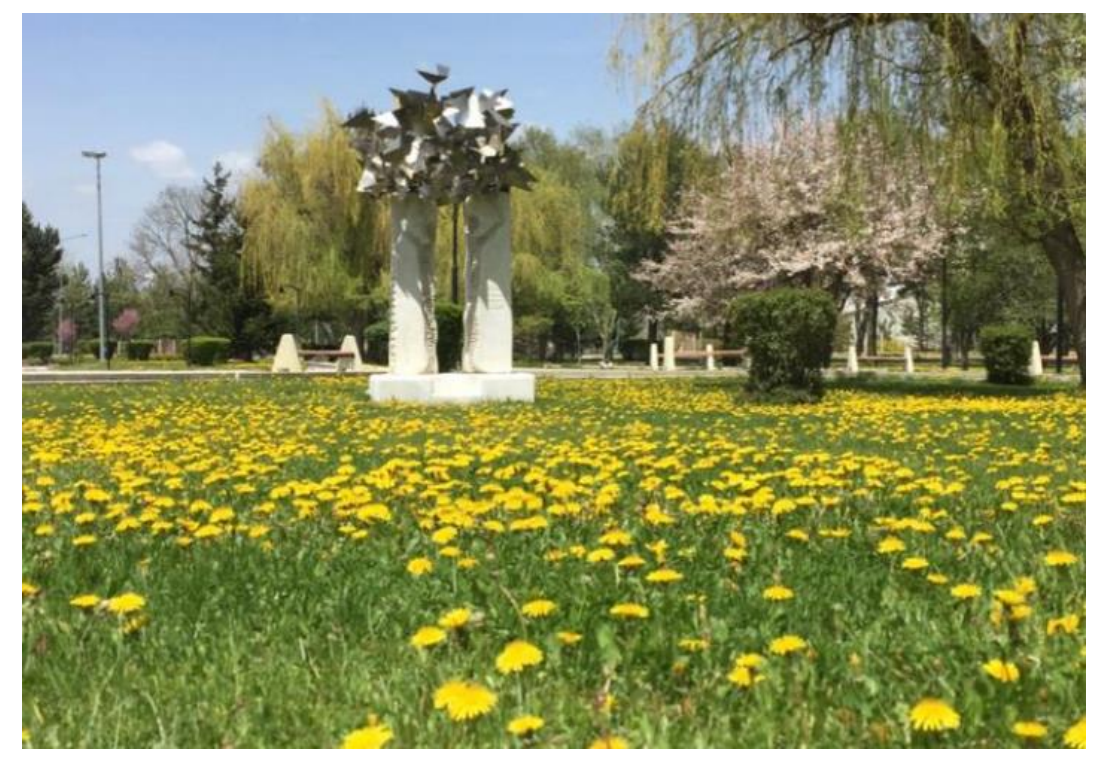

Şekil 1. Karahindiba (Fotoğraf için Prof. Dr. Funda Bayındır’a teşekkür ederiz.)

\subsection{Guayule (Parthenium argentatum A. Gray)}

Guayule Orta Kuzey Meksika ve Güneybatı Teksas'ın Chihuahuan çölüne özgü bir bitki olan, yerli doğal kauçuk (NR) ve hipoalerjenik lateks için alternatif kaynaklardan biri olarak kullanılabilen çok yıllık odunsu bir çalıdır. Yüksek proteinli guayule lateksi de kahverengi/yeşil renklidir. Karahindiba gibi Compositae familyasından olan guayulenin kauçuk kaynağ kökündedir. Kauçuk içeriği ise \%3-12 civarındadır. Benzer şekilde Pirelli lastik firması da genelde kurak 
iklimlerde yetişen, besin maddesi olarak kullanılmayan, az miktarda suya gerek duyan ve böcek ilacı kullanmadan büyüyebildiği için kauçuk üretiminde kullanılan Hevea brasiliensis bitkisine bir alternatif olan guayuleden performans lastiği üretmiştir. İki yıl süren laboratuvar testleri sonrasında, guayuleden elde edilen doğal kauçukla üretilen prototip performans lastikleri, Vizzola ve Balocco pistlerindeki turlarından başarıyla ayrılmıştır (http://www.ekonomiyontem.com.tr).

Guayule kauçuğu 1940'larda Türkiye'de denemeye alınmış ve bu bitkinin Muğla'nın Köyceğiz İlçesi'nden Suriye sınırına kadar uzanan ve Toroslar'ın güneyinde kalan bölgede yetiştirilebileceği anlaşılmıştır, özellikle Antalya'nın kıraç toprakları bu bitkinin yetişmesi için çok uygundur (Kaştan, 2019).

\subsection{Dikenli Marul (Lactuca serriola L.)}

Doğal kauçuk (cis-1,4-poliizopren), binlerce ürün üretiminde kullanılan en önemli türetilmiş biyopolimerlerden biridir. Bitki kaynaklı kauçuk, gerilme mukavemeti, 1sı ve darbe dayanımı gibi fiziksel özellikleri sentetik poliizopren ile kıyaslandığında eşsizdir. Birçok bitki kauçuk polimerler yapabilmesine rağmen, az sayıda bitki yüksek molekül ağırlıklı molekülleri sentezleyebilir. Yabani bir ot olan dikenli marul da bunlardan biridir. Dikenli marul yetiştiği dönemde $150 \mathrm{~cm}$ kadar boylanabilen otsu bir bitkidir. Dikenli marul kökleri toprak yapısına bağlı olarak oldukça kuvvetli gelişen ve derinlere giden kazık köklü bir bitkidir. Compositae familyasındandır. İstilacı yabancı otlardan olan dikenli marula Doğu Anadolu Bölgesi'nde yaygın olarak rastlanmaktadır (Çoruh, 2010). Yakın zamanda yapılan bir araştırma dikenli marulun, kauçuk ağacı ve guayuleninkine benzer bir moleküler ağırlığa sahip küçük miktarlarda kauçuk içerdiğini gösterdi. Bu, bitkilerdeki kauçuk biyosentezini moleküler düzeyde incelemek için yeni bir firsat sağlar, ancak bunun bir kauçuk kaynağı olma potansiyeli belirsizdir (Bushman ve ark., 2006). Doğu Washington'da dikenli marul biyotiplerinin bir koleksiyonundan yüksek molekül ağırlıklı, \%2,2-\%4,9 kauçuk elde edilmiştir. Kauçuk polimerler, nükleer manyetik rezonans spektroskopisi ile cis-1,4-poliizopren olarak teyit edilmiş ve çok az trans-poliizopren saptanmıştır. Fiziksel özellik analizi, dikenli marul kauçuğunun, Brezilya kauçuk ağacından türetilen lastiklere eşit veya ondan daha iyi özelliklere sahip olduğunu göstermiştir. Dikenli marul, son kullanım için istenen fiziksel özelliklere sahip potansiyel bir doğal kauçuk kaynağıdır. (Bell, 2013). Marul ve muhtemelen diğer bitkilerde, doğal kauçuk sentezi için gerekli anahtar enzimlerin bulunduğu kanıtlanmıştır. Doğal kauçuk biyosentezini yöneten moleküler mekanizmayı incelemek için baz model olarak marulun alındığı ve 
amacı yeni bitkisel kaynaklardan doğal kauçuk oluşturmak için en uygun bitki enzimlerini bulmak olan çalışmalar sürmektedir (Kaya, 2015).

\subsection{Altınbaşak (Solidago altissima L., S. canadensis L.)}

Ilıman iklimlerde yetişebilen diğer birkaç bitki, özellikle doğal kauçuğun fiyatı veya erişilebilirliğinin sorun olduğu zamanlarda (1920'ler, İkinci Dünya Savaşı, 1970'ler) kauçuk üretimi için test edildi. 1920'lerin sonunda kauçuğun fiyatı yükseldiğinde, Thomas Edison, Henry Ford ve Harvey Firestone, kauçuk kalitesi ve miktarı için 17.000'den fazla fabrikayı tarayan Edison Botanik Araştırma Şirketini kurdu. Kapsamlı araştırmalarla altın başaktan (Solidago altissima, $S$. canadiensis), ortalama $1 \mathrm{~m}$ yüksekliğe kadar büyüyen yaygın bir yabani ot, \% 5'lik bir lateks verimi üretti. Hibridizasyon yoluyla Edison, 3 m'yi aşan altın başak üretti ve\% 12 lateks verdi. Ne yazık ki ortaya çıkan kauçuk, Henry Ford tarafından yapılan testlere göre düşük kalitedeydi. Kauçuk kalitesini iyileştirmenin alternatif bir yolu ticari olarak uygun miktarlarda yüksek molekül ağırlıklı kauçuk üreten transgenik bitkiler üretmektir. Bu stratejiler, kauçuk verimini ve kalitesini etkileyen tüm biyokimyasal faktörlerin tam olarak anlaşılmasını gerektirir (Beilen ve Poirier, 2007). Solidago taksonlarından S. canadensis türü bir yüksek lisans çalışması esnasında Kastamonu'da tespit edilmiştir (Terzioğlu ve ark., 2003; Aykurt, 2018).

$\mathrm{Bu}$ bitkilerin dışında Sapotaceae ailesinden gelen Gutta-Percha ağacı (Eucommia ulmoides), Brezilyadaki Bolle, Bully, veya Bullet diye bilenen ağaçtan elde edilen Balata bitkilerinden kullanışlı ve ekonomik kauçuk ürünleri üretilebildiği (Vahapoğlu, 2007), Compositae familyasından olan Tragopogon aureus Boiss, halk arasında "yemlik" veya "tekesakalı" olarak bilinen ve Doğu Anadolu'da yetişen bitki (Gerez ve Korkut, 2019) gibi pek çok bitkinin de (Mooibroek, 2000) doğal kauçuk içerdiği belirlenmiştir.

Ülkemizin hemen her bölgesinde görülebilen ve doğal kauçuk için potansiyel kaynak oluşturabilecek bu bitkilerin üniversitelerimiz ve araştırmacılarımız tarafından incelenmesi, ülke ekonomisine katkı sağlayacak araştırmalara ışık tutacaktır.

\section{Kauçuk içeren bitkilerden elde edilebilecek diğer katma değeri yüksek maddeler}

Artan enerji talebi ve azalan fosil kaynaklarının yanı sıra çevresel etkilere dair endişelerin artmasıyla çeşitli bitkilerden elde edilebilecek yan ürünlerin değerlendirilmesi giderek önem kazanmaktadır. Guayule, bilim adamlarının ilgisini çeken kauçuk ve lateks içeriği gibi popüler 
özelliklerin yanı sıra, yüksek oranda reçine ve küspe (\% 85-90) içermesi nedeniyle ilaç ve biyoyakıt endüstrileri için yenilenebilir organik bir kaynak olarak da kullanılabilir (Nakayama, 2005).

Guayule reçinesi koyu kahverengi, yüksek viskoziteli, yapışkan, suda çözünmeyen, oda sıcaklığında güçlü, belirgin bir çam / narenciye kokusu olan yarı katı sıvıdır. Reçine, çok çeşitli ikincil metabolitler: monoterpenler ve seskiterpenler (uçucu yağlar); seskiterpen esterler (guayulinler); triterpenoidler (argentatinler); sinamik, p-anisik, palmitik, stearik, oleik, linoleik ve linolenik dahil organik asitler ve polifenolikler içerir. Guayule sapları ve kökleri ise, önemli miktarlarda (\% 10-15) guayulin A (sinnamik asidin parteniol esteri, $\mathrm{C}_{24} \mathrm{H}_{30} \mathrm{O}_{2}$ ) ve guayulin $\mathrm{B}$ (anisik asidin parteniol esteri, $\mathrm{C}_{23} \mathrm{H}_{30} \mathrm{O}_{3}$ ) içerir (Cheng ve ark., 2020). Bu reçine terpen açısından zengin olduğu kadar yüksek kalorifik değere sahip az miktarda artık kauçuk ta içerir. Bu yoğun hidrokarbon bileşenlerinin varlığı, guayule küspesinin çoğu biyokütle kaynağına kıyasla piroliz yöntemleriyle daha yüksek kaliteli sıvı yakıtların üretiminde kimyasal bir avantaja sahip olduğunu göstermektedir (Boateng ve ark., 2015; Boateng ve ark., 2009). Bu benzersiz özellik, halihazırda lateks ekstraksiyon işlemiyle toplanmış, kurutulmuş ve boyutu küçültülmüş olması gerçeğiyle birleştiğinde guayule küspesi, yenilenebilir hidrokarbon yakıtların üretimi için aynı yerde bulunan bir piroliz biyorafinerisi için oldukça uygun bir yakıt besleme stoğunu temsil etmektedir (Sabaini ve ark., 2017). Hasat edilen guayulenin edinim maliyeti metrik ton başına 100 \$ ve 200 \$ arasında değiştiğinden ve bunun sadece küçük bir kısmı çıkarılabilir kauçuk olduğundan, guayule-kauçuk endüstrisinin başarılı gelişimi, nihayetinde küspenin ekonomik kullanımının geliştirilmesine bağlı olacaktır (Sfeir ve ark., 2014; Sproul ve ark., 2020).

TKS köklerine yapılan ayrıntılı bir analiz sonucunda TKS' nin yalnızca NR değil, aynı zamanda inülin ve proteinler dahil olmak üzere önemli pek çok hammadde kaynağ potansiyeline sahip olduğu görülmüştür. Analiz kökün \% 5,4'ünün (g/g kök kuru bazda) kauçuktan oluştuğunu ve \% 1,7'sinin asetonla ekstrakte edilebildiğini (esas olarak steroller) göstermiştir. Kökün yaklaşık \% 60'1 (g / g kuru bazda) sıcak suyla ekstrakte edilebilmiş ve inülin ve sükroz başta olmak üzere çözünür şekerler ile proteinler elde edilmiştir. Çözünmeyen bileşenler arasında selüloz, hemiselüloz (ksilan, mannan, arabinan, galaktan), lignin, protein ve pektin bulunmuştur. $\mathrm{Bu}$ sonuçlar, TKS' nin NR, inülin, protein, kimyasallar ve ekstrakte edilen köklerin enzimatik hidrolizi ile biyoyakıt üretimi için ekonomik bir biyo-rafineri hammaddesi olabileceğini göstermektedir (Ramirez-Cadavid ve ark., 2017).

S. canadensis' in çiçeklerinden sıcak alkali ekstraksiyon ile polifenolik-polisakkaritprotein kompleksi izole edilmiştir. $\mathrm{Bu}$ kompleksin kompozisyon analizi (ağırlıkça), 
karbonhidratların (\%43) proteinin (\%27), fenoliklerin (\%12), üronik asitlerin (\%10) ve inorganik materyalin (\%8) varlığını ortaya koymuştur. Karbonhidrat kısmı, nötr şekerler bakımından zengindir (\%81) ve üronik asitler daha düşük miktarda (\%19) belirlenmiştir. Karbonhidrat kısmının monosakkarit analizi, ramnoz (\%23), arabinoz (\%20), üronik asit (\%19), galaktoz (\%17) ve glukoz (\%14) varlığını göstermiştir ve böylece S. canadensis kompleksinde ramnogalakturonan ve arabinogalaktan varlığını belirlemiştir (Sutovska ve ark. , 2013). Biyokimyasal çalışmalar Solidago türlerinin çeşitli terpenler içerdiğini göstermektedir. Dört asetilen (alkin) ve üç terpen S.canadensis'in köklerinden izole edilmiş ve saptanmıştır. (E)-dehidromatricaria lakton da bu türde ilk kez bildirilen bileşiklerden biridir. S. canadensis'in yaprak ve çiçeklerinin metanollü ekstrelerinde farmakolojik alanda öneme sahip beş bileşik, klorojenik asit, rutin, hiperosit, kersitrin ve izokersitrin tespit edilmiştir (Aykurt, 2018).

\section{Bitkilerden doğal kauçuğun elde edilme yöntemleri}

Literatürde bitkilerden doğal kauçuk üretiminde yaygın olarak iki farklı kazanım yöntemi sunulmuştur. Bunlardan biri flotasyon yöntemi (Cornish ve ark., 1999; Buranov ve ark., 2010; Glensid ve Edwards, 1946) diğeri ise eş zamanlı veya birbiri ardınca su , aseton ve heksan ekstraksiyonunu içeren sıralı ekstraksiyon ( Ramirez-Cadavid ve ark., 2018) yöntemidir.

\subsection{Flotasyonla kauçuk eldesi}

Yüzdürme ile ayırma yöntemi olan flotasyonla kauçuk eldesi için yöntem basamakları genel olarak şöyle sıralanabilir:

1- Taze kökler budaklarından ayrılıp suyla kaynatılır. Böylece karbonhidratlar uzaklaştırılır.

2- $\quad$ Kalan bitki kökü çakıllı bir ögütücüde suyla öğütülür. Böylece NR suya geçer.

3- Sarsaklı bir elekten geçen süzüntü suyla seyreltilir. Su üstünde yüzen kauçuk toplanır.

4- Daha sonra kalıntılardan kurtulması için suyla kaynatılır (Glensid ve Edwards., 1946).

Bir diğer flotasyonla ayırma işleminde önce bitkiler kuru kökte ağırlıça \%0-30 nem içerecek şekilde kurutulur. Daha sonra 1000 RPM ile dönen ağır bir değirmen taşına beslenir. Öğütülen bitkiden kauçuk aglomere olarak ayrılır. Bir elek ve fan ile üflenen hava ile bitkinin diğer kısımları uzaklaştırılır. Elde edilen kauçuk 20:1 oranında 30-60 ${ }^{\circ} \mathrm{C}$ su ile1000-10.0000 RPM hızla karıştırılır. Sabun ilavesiyle kauçuğun aglomerasyonu önlenir. Yüzeydeki kauçuk sıyrılır. Kalan bitki çöker (Buranov, 2010). Cornish ve ark. (1999) ise laboratuvar ölçekli çalışmalarında belli 
Korkut, Ö., Gerez, E., Uluslararası Doğu Anadolu Fen Mühendislik ve Tasarım Dergisi / International Journal of Eastern Anatolia Science Engineering and Design (IJEASED)

(2020) 2(2):216-228

boyutlarda kestikleri guayule dallarını $\mathrm{pH}$ değeri 10 veya 11 olan $\mathrm{Na}_{2} \mathrm{SO}_{3}$ ve $\mathrm{NH}_{3}$ içeren tampon çözeltilerinde ögütmüş ve oluşan bulamaçları odunsu parçacıklardan filtrasyon ile ayırmışlardır. Süzüntüler santrifüjlendiğinde kremsi lateks tabakası yüzeyde oluşmuştur. Bu tabaka ayrılarak kurutulmuştur.

\subsection{Ekstraksiyonla kauçuk eldesi}

Hevea lateks kauçuğun aksine guayule gibi bitkilerin kauçuğu, kabuk ve odunsu dokuların parankim hücreleri içinde depolanır, bu nedenle hücreleri bozmak için öğütme gerekir (Bates ve Cornish, 2018). Eşzamanlı ekstraksiyonda, polar olmayan ve polar çözücülerin bir karışımı (Ağırlıkça \%20 aseton ve ağırlıkça \%80 heksan veya pentan) ile öğütülmüş bitkinin teması sağlanır. Yüksek molekül ağırlıklı kauçuğu çöktürmek için oluşan misele ek polar çözücü eklenir. Çözücü ekstraksiyonundan elde edilen verimi birçok faktör etkileyebilir: solvent tipleri ve oranları, temas süresi, konsantrasyon, sıcaklık, biyokütle hazırlama (ön ekstraksiyon), nem içeriği, ekstraksiyon tasarımı vb. (Huang ve ark., 2015 ).

Eşzamanlı çözücü ekstraksiyon yöntemi ile reçine ayrıldığından daha kaliteli bir kauçuk üretilebilir ancak bu işler zaman alıcı olduğu için yeni geliştirilen cihazlarla yapılan sıralı ekstraksiyon yöntemi hızı, doğruluğu ve tekrarlanabilirliği artırdığından daha çok tercih edilecektir. $\mathrm{Bu}$ yönteme ait basamaklar şöyle sıralanabilir;

1- Kökler $50{ }^{\circ} \mathrm{C}$ 'de hava üflemeli konvektif bir kurutucuda 48 saat kurutulur.

2- $\quad$ Diğer adım öğütme işlemidir. Burada amaç kimyasal işlem uygulamadan önce yüzey alanını artırmak ve standart boyuta getirilmiş örnek hazırlamaktır. Bunun için bitki kökleri, yaprak ve sapları ayrılarak, saman gibi maddelerin öğütülmesinde kullanılmak üzere tasarlanmış bir ögütücüde öğütülür. Daha sonra tekrar sabit ağırlığa gelinceye dek $45^{\circ} \mathrm{C}$ 'de kurutulan bitki parçaları işleme alınıncaya dek $+4^{\circ} \mathrm{C}$ 'de ağzı kapalı poşetlerde bekletilir. Kül tayini bu aşama sonunda elde edilen numuneye yapilır.

3- Belirli bir miktar alınan numune analitik ögütücü ile 20s daha öğ̈̈tülerek boyutu daha da küçültülür, elenir ve bir ASE (Accelerated Solvent Extractor) cihazı ile sırasıyla su, aseton ve heksan ile ekstrakte edilir. Her bir ekstrakt ayrı kaplarda depolanır. Burada su ile ekstraksiyon önceden yapılmazsa bitkideki karbonhidrat ve türevleri (özellikle inülin) kauçukla birlikte üründe bulunacağından analiz sonucunda hataya neden olacaktır. Asetonla ekstraksiyonla ise reçine türevleri ayrılmış olur. Heksan ekstraksiyonundan elde edilen ekstrakt ise kauçuğu içerir (RamirezCadavid ve ark., 2017, 2018). 


\section{Sonuç}

Petrol bazlı sentetik kauçuğa göre daha üstün özelliklere sahip doğal kauçuğun ana kaynağ1 olan Hevea brasiliensis türünün dünyanın sadece belli yerlerde yetişmesi nedeniyle ülkeleri bu bağımlılıktan kurtaracak yeni arayışlar sürmektedir. Bu çalışmada ticari anlamda kauçuk üretimi için kullanılan karahindiba, guayule, dikenli marul ve altınbaşak bitkileri ayrıntılı olarak ele alınmıştır. Bu bitkiler sadece doğal kauçuk kaynağı değil, aynı zamanda biyorafineriler için de iyi bir ham madde olmaları ve katma değeri yüksek başka maddeler içermeleri nedeniyle dikkatleri çekmektedirler. Dört mevsimin yaşanabildiği ve pek çok endemik bitki türüne ev sahipliği yapan ülkemizde de yetişebilen bu dört bitkinin yanı sıra doğal kauçuk kaynağı olmaya aday pek çok bitki mevcuttur. Uygun bitkilerden daha yüksek verimle kauçuk elde edebilmek için yapılacak kültüre alma denemeleri, genetik çalışmalar ve etkili ayırma yöntemlerinin geliştirilmesine dayalı çabalar oldukça kıymet arz etmektedir.

\section{Kaynaklar}

Aykurt, F. (2018). Türkiye'de yetișen solidago taksonlarının fitoterapi açısından değerlendirilmesi, Ankara Üniversitesi Sağlık Bilimleri Enstitüsü, Farmakognozi Anabilim Dalı tezsiz yüksek lisans dönem projesi, Ankara.

Bates, G. M., Cornish, K. (2018). Rapid and complete removal of guayule (Parthenium argentatum) leaves by cryodefoliation, and freeze and thaw induction of rubber particle coagulation, Ind. Crops Prod., $125,491-495$.

Beilen, J. B. van, and Poirier, Y. (2007). Establishment of new crops for the production of natural rubber,Trends Biotech., 25, pp. 522-529.

Bell, J. L. (2013). Biochemical and genetic Characterization of rubber Production in prickly Lettuce (Lactuca serriola L.), Doktora Tezi, Washıngton State Unıversity, Molecular Plant Sciences Graduate Program.

Boateng, A. A., Mullen C. A., Goldberg, N. M., Hicks, K. B., C. M. McMahan, Whalen, M. C., Cornish, K. (2009). Energy-dense liquid fuel intermediates by pyrolysis of guayule (Parthenium argentatum) shrub and bagasse, Fuel, 88 (11), 2207-2215.

Boateng, A. A., Mullen, C. A., Elkasabi, Y., McMahan, C. M. (2015). Guayule (Parthenium argentatum) pyrolysis biorefining: production of hydrocarbon compatible bio-oils from guayule bagasse via tailgas reactive pyrolysis, Fuel, 158 , 948-956.

Bouchardat, C. 1879., Compt. rend, 80.

Buranov, A. U., Elmuradov, B.J., (2010). Extraction and characterization of latex and natural rubber from rubber-bearing plants, J. Agric. Food. Chem. 58, 734-743.

Bushman, B. S., Scholte, A. A., Cornish, K., Scott, D. J., Brichta, J. L., Vederas, J. C., Ochoa, O., Michelmore, R.W., Shintani, D. K., Knapp, S. J. (2006). Identification and comparison of natural rubber from two Lactuca species, Phytochem., 67, 2590-2596.

Cheng, F., Dehghanizadeh, M., Jacqueline, M., Jarvis, F., Holguin, O., Brewer, C. E., (2020), Characterization and evaluation of guayule processing residues as potential feedstock for biofuel and chemical production, Industrial Crops and Products, 150, 112311.

Ching C, Chiang K. (2013). Natural Rubber Biyosynthesis :Perspectives From Polymer, UMI 3671070, ProQuest LLC. 789 East Eisenhower Parkway P.O. Box 1346 Ann Arbor, MI 48106 - 1346. 
Korkut, Ö., Gerez, E., Uluslararası Doğu Anadolu Fen Mühendislik ve Tasarım Dergisi / International Journal of Eastern Anatolia Science Engineering and Design (IJEASED)

(2020) 2(2):216-228

Cornish, K,. Chapman, M. H., Nakayama, F.S. Vinyard, S.H. Whitehand, L.C. (1999). Latex quantification in guayule shrub and homogenate", Ind. Crops Prod., 10, 121-136.

Cornish, K., (1996). Hypoallergenic natural rubber products from Parthenum argentatum (gray) and other non-Hevea brasiliensis species. US Patent 5,580,942.

Cornish, K., McCoy III, R. G., Martin, J. A., Williams, J., Nocera, A. Jr, (2011). Biopolymer extraction from plant materials. US Patent 7923,039 B2.

Çoruh, İ. (2010). Erzurum yöresinde bazı korunga ekim alanlarında bulunan yabancı otlar, yoğunlukları ve rastlama sıklıkları, Anadolu Tarım Bilim Dergisi, 25(2), 89-93.

Erdoğan N., Büyükkartal H. N., Karadeniz A., Çölgeçen H., (2012). Sertavul geçidi ve Mut (Mersin) çevresinde yayı1lış gösteren bazı Euphorbia L. taksonlarının anatomik yönden incelenmesi, Mehmet Akif Ersoy Üniversitesi Fen Bilimleri Enstitüsü Dergisi, 3 (1): 22-31.

Gerez, E., Korkut, Ö. (September, 2019), Production of Natural Rubber from Tragopogon aureus Boiss, 3rd International Conference on Advanced Engineering Technologies, ICADET, Bayburt.

Glenside, R. K. E., and Edwards P. W. (1946). Process for recoverng fruber from fleshy plants, United States Patent Office, Serial No. 513,458, Patented Jan. 15,.

Gürsoy, H., Karahindiba'yı Kauçuka Dönüştüren Continental'den Yeni Yatırımlar, https://www.continentallastikleri.com.tr/binek/basin/haberler/taraxagum-lab-anklam, Erişim tarihi: 30.08 .2020 .

Hayashi, Y. (2009). "Production of natural rubber from para rubber tree." Plant Biotechnology, 70: 67-70.

http://www.ekonomiyontem.com.tr/pirelli-den-guayule-kaucugundan-performans-lastigi/3406/, Erişim tarihi: 30.08.2020.

Huang, Y., Mouri, H., Beaulieu, M. (2015). Processes for the removal of rubber from tks plant matter, United States Bridgestone Corporation $\quad$ (Tokyo, JP) 20150073113 http://www.freepatentsonline.com/y2015/0073113.html

Kaştan, Y. (Nisan, 2018). Antalya'da tarım faaliyetlerinin Cumhuriyet Dönemi tarihi gelişimi, Türkiye'de tarım politikaları ve ülke ekonomisine katkıları uluslararası sempozyumu, ŞANLIURFA, sayfa 576600.

MEGEP Yayınları, 2008, Compositae Familyas1, http://hbogm.meb.gov.tr/modulerprogramlar/kursprogramlari/bahcecilik/moduller/compositae_familya s\%C4\%B1.pdf, Erişim tarihi: 30.08.2020.

Mooibroek, H., ve Cornish, K. (2000). Alternative Sources of Natural Rubber , Applied Microbiology and Biotechnology, 53: 355- 365

Nakayama, F. S. (2005), Guayule future development, Industrial Crops and Products, 22, 1, 3-13.

Kaya, N. (2015). Bitkilerden Kauçuk Üretme Yolunda Araştırmalar Hız Kazandı, Kauçuk Dergisi, Haziran, Say1 56, sayfa 56, ISSN: 2146-1821.

PLASFED, Türkiye Plastik Sektör 2018 yarıy1l tahminleri, http://rapor.plasfed.org.tr/admin/PICS/files/PLASFED_2018_IlkYariDegerlendirmesi.pdf, Erişim tarihi: 30.08 .2020 .

Radcliffe-Smith, A. (1982). Euphorbia. In Davis, P.H. (ed.). Flora of Turkey and The East Aegean Island, Edinburg University Press., Vol. 7, pp. 571- 630.

Ramirez-Cadavid, D. A, Cornish K, Frederick C. M. Jr. (2017). Taraxacum kok-saghyz (TK): compositional analysis of a feedstock for natural rubber and other bioproducts , Industrial Crops \& Products ,107, 624-640.

Ramirez-Cadavid, D. A, Valles-Ramireza, S, Cornish K, Frederick C. M. Jr. (2018). Simultaneous quantification of rubber, inulin, and resins in Taraxacum koksaghyz (TK) roots by sequential solvent extraction", Industrial Crops \& Products ,122, 647-656.

Sabaini, P.S., Boateng, A. A., Schaffer, M., Mullen, C. A., Elkasabi, Y., McMahan, C. M., Macken, N. (2018). Techno-economic analysis of guayule (Parthenium argentatum) pyrolysis biorefining: Production of biofuels from guayule bagasse via tail-gas reactive pyrolysis, Industrial Crops and Products, 112, 82-89.

Sfeir, N., Chapuset, T., Palu, S., Lançon, F., Amor, A., García García, J., Snoeck, D. (2014). Technical and economic feasibility of a guayule commodity chain in Mediterranean Europe, Ind. Crop. Prod., 59, $55-62$. 
Sproul, E., Hailey M., Clark S., Joram Robbs, S., Khanal S., Mealing, VeeAnder, Landis, Amy E., Fan, Sun N., Jason O., Quinn, C. (2020). Integrated techno-economic and environmental analysis of guayule rubber production, Journal of Cleaner Production, 273, 122811.

Sutovska M, Capek P, Franova S, Gancarz R, Kocmalova M, Pawlaczyk I. (2013). Characterization and biological activity of Solidago canadensis complex. International Journal of Biological Macromolecules, 52, 192-197.

Şenel G., Özkan M., Özdemir C. (1996). Euphorbia helioscopia L. ve Euphorbia amygdaloides L. var amygdaloides üzerinde anatomik bir çalışma, Ondokuz Mayıs Üniversitesi Fen-Edebiyat Fakültesi Fen Dergisi, 7 (1), 153-168.

Terzioğlu, S., Anşin, R,, Kanoğlu E. (2003). A New Record for Turkey: Solidago canadensis L. Tübitak, Turkish Journal of Botany, 155- 157.

Vahapoğlu, V. (2007) Kauçuk türü malzemeler I. doğal kauçuk, C.B.Ü. Fen Bilimleri Dergisi, 3.1, 57-70. 